\title{
Search for Inclusive Language
}

\author{
A New Stage of Awareness Inside the Interreligious Dialogue \\ Movement (United Religions Initiative / 2000-2006)
}

\section{Introduction}

Interreligious dialogue first began within the context of ecumenism and then gradually extended outward from Christian circles to include world religions. ${ }^{1}$ Most scholars agree that the Parliament of World Religions in 1893 initiated the first step towards interreligious dialogue. ${ }^{2}$ Marianne Moyaert argues that the 1893 meeting symbolizes the "beginning of the interfaith movement" that was rooted in "positive and constructive relations between world religions."3 Moyaert asserts that replacing polemics and apologetics with positive interreligious engagement and 'dialogue' was a representation of modern ideals based

\begin{abstract}
Note: I would like to thank the staff of the United Religions Initiative (URI) for their help during this research project. I would like to thank Sally Mahe for her insights into the dialogical models of Appreciative Inquiry (Al) and Chaordic organising that make URI so distinct in the field of interreligious dialogue. Conversations with Victor Kazanjian were immensely helpful and enabled me to understand the structure of URI. A special meeting with Bishop William E. Swing during my research at the archive was particularly poignant and meaningful.

I want to express deep thanks to the URI archivist, Juliet Demeter who was immensely helpful with locating the archival materials that were significant to this project. Conversations with Krithika Harish and her description of Cooperation Circles (CCs) and how they function under the URI umbrella were very illuminating. Her insight into the democratic structure of URI was significant and informative in the analysis of this paper. Karen Hernandez, Isabelle Ortega, Diana Conan, Pamela Banks, Brian Devine, Kay Markham, and Ofelia Trevino supported me during my research and offered friendship and warmth, all of which made this research trip a very special experience. Maria Crespo De Mafia was incredibly kind and welcoming and made every effort to make me feel a part of the URI family before I even arrived in San Francisco. Finally, I would like to thank Karsten Lehmann for this research opportunity and for the support throughout this project.
\end{abstract}

1 Thomas Madathilparampil Mammen, Towards a Wider Ecumenism (Bangalore: Asian Trading Company, 1993).

2 Marianne Moyaert, "Interreligious Dialogue," in Understanding Interreligious Relations, ed. David Cheetham, Douglas Pratt, and David Thomas (Oxford: Oxford University Press, 2013), 193. 3 Moyaert, "Interreligious Dialogue," 195.

Ә OpenAccess. () 2021 Sara Singha, published by De Gruyter. (cc) BY-NC-ND This work is licensed under the Creative Commons Attribution-NonCommercial-NoDerivatives 4.0 License. 
on "freedom of religion, respect for otherness, and tolerance." 4 The initial movement, then, was motivated by a number of pertinent social factors including the end of colonialism and the rise of post-colonialism, both of which challenged the premise of Christian superiority and exclusivity. ${ }^{5}$ Therefore, the early interreligious dialogue movement stemmed, at least partially, from a desire to engage religious diversity from a non-imperialistic theological worldview. ${ }^{6}$

Since its inception, interreligious dialogue has been replete with internal fissures. One aspect of interreligious dialogue that is pertinent to this project is the inherent tension between theological openness and religious identity. ${ }^{7}$ Is it possible to maintain one's theological identity while engaging the 'other' in truthful and respectful terms? The interreligious dialogue movement and its proponents have struggled with this question. A strong proponent of interreligious dialogue, American theologian John Hick is often critiqued because his pluralistic approach blurs the lines of religious identity. For example, Hick asserts that all religions have the same soteriological goal. ${ }^{8}$ For Hick, every religion is an equally valid path to God and marks a movement from "ego-centeredness to reality-centeredness." 9 Although religions manifest different 'truth claims' for Hick, these are simply indications of historical and cultural distinctions. Therefore, Hick contends that all religions are true. ${ }^{10}$ American theologian Paul Knitter agrees with Hick. Knitter asserts that Christian superiority needs to be re-evaluated. ${ }^{11}$ Knitter notes that while the New Testament contains 'truth claims', these are 'confessional' and need to be interpreted within their historical-cultural context. ${ }^{12}$ As such, both Hick and Knitter claim that exclusivist theology cannot be sustained in an increasingly globalized world.

Knitter, in particular, is a proponent of interreligious dialogue. He argues that such engagement is necessary for the ethical wellbeing of society. Knitter favours an orthopraxic model of dialogue that is motivated by ethical issues in-

4 Moyaert, “Interreligious Dialogue,” 195.

5 J. Hill Fletcher, "Religious Pluralism in an Era of Globalization: The Making of Modern Religious Identity,” Theological Studies 69 (2008): 395.

6 Moyaert, "Interreligious Dialogue," 197.

7 Moyaert, “Interreligious Dialogue,” 208.

8 John Hick, An Interpretation of Religion: Human Responses to the Transcendent (New Haven: Yale University Press, 2004), 36.

9 Hick, An Interpretation of Religion, 36.

10 Hick, An Interpretation of Religion, 36.

11 Paul F. Knitter, No Other Name? A Critical Survey of Christian Attitudes towards the World Religions (New York: SCM Press, 1985), 95-93; See also Paul F. Knitter, Jesus and the Other Names: Christian Mission and Global Responsibility (New York: Orbis Books, 1996).

12 Knitter, No Other Name?, 93. 
cluding poverty, violence, marginalisation, and oppression. ${ }^{13}$ "Human beings, as individuals and as communities, have a global responsibility, that is, a responsibility to promote the wellbeing and life of a threatened humanity and planet." 14 Similarly, theologian Hans Küng asserts that "one world needs one basic ethic" for survival given the extent of ecological and socio-political deterioration. ${ }^{15}$ However, despite Hick's soteriological model and Knitter and Küng's orthopraxic model, some theologians remain suspicious of the pluralistic enterprise. This hesitation, in part, arises from the notion that religions are circumscribed by theological 'truth claims' that, while universal in application, are particular in confession. Therefore, to affirm the truth of every religion, as Hick suggests, is tantamount to denying the 'truth claims' of all religions.

In the American context, most critiques of interreligious dialogue and pluralism tend to emerge from conservative Christian circles. For example, American theologian Harold Netland has multiple concerns about interreligious dialogue. Netland argues that religious pluralism is rarely genuine. ${ }^{16}$ He asserts that most dialogue is usually a form of 'pseudo inclusivism' that tends to privilege one worldview over the other. ${ }^{17}$ He further claims that the danger of interreligious dialogue and pluralism "strike at the heart of Christian faith, touching every major area of theology, including theological method, revelation, the doctrine of God and, most, obviously, Christology and soteriology." 18 The issue for Netland and other conservative Christians is rooted in the tension between the particularity of Christ and the universality of his message. The concern arises from striking a theological balance between engaging the 'other' while upholding the 'truth claims' of the Christian tradition.

In North America, there is an inherent tension between engaging the religious 'Other' and remaining within the doctrinal boundaries of Christianity. This significant aspect of the interreligious dialogue movement is manifested through the work of the United Religions Initiative (URI). Since its establishment on 26 June 2000, the URI has evolved from a small group of visionary people led

13 Paul F. Knitter, One Earth, Many Religions: Multifaith Dialogue and Global Responsibility (New York: Maryknoll, 1995).

14 Knitter, No Other Name?, 70.

15 Cited in Knitter, One Earth, Many Religions, 65.

16 Harold Netland, Encountering Pluralism: The Challenge to Christian Faith and Mission (Illinois: InterVarsity Press, 201), 216-218.

17 Netland, Encountering Pluralism, 216-218.

18 Netland, Encountering Pluralism, 14. 
by Episcopal Bishop William E. Swing into a global interfaith organization. ${ }^{19}$ In his monograph, the Coming of the United Religions, Swing notes that when he first raised the idea to friends, "not one thought a United Religions could be achieved. Not one advised it. No colleague made partnership with it."20 The initial response was hence, negative. Swing was attacked by conservative Christians, interfaith leaders, and journalists precisely because of his specific commitment to interreligious dialogue. Many critics argued that the United Religions was an affront to ecumenism. ${ }^{21}$ As such, this vision did not have much hope of becoming actualized. ${ }^{22}$ However, despite the initial response, Swing pursued his idea. Similar to Knitter and Küng, Swing was rooted in the orthopraxic model of dialogue and believed that interreligious engagement was necessary for the "health of the planet."23

Today, URI is one of the largest interreligious organizations in the world. URI has a presence in every continent and is active around the world, in countries such as Cambodia, India, Iraq, Jordan, Nigeria, Pakistan, the Philippines, South Korea, Uganda, and Venezuela. ${ }^{24}$ URI has an operational structure based on Cooperation Circles (CCs), which are autonomous units that have signed the URI Charter. Nearly 640 CCs are active in almost every region of the world

19 The Episcopal Church (TEC) is the American based church of the Anglican Communion. It has nine provinces and dioceses in the United States, Taiwan, Micronesia, the Caribbean, and Central and South America. The TEC emerged as its own independent church during the American Revolution when it separated from the Anglican Communion in the Church of England. The TEC is generally one of the more "liberal" mainline Protestant churches in the United States and is active in women's ordination and gay and lesbian ordination. Because of their liberal attitude, the TEC has come under attack from more conservative Christian groups within the United States that do not support gay and lesbian ordination and/or female clergy.

20 William E. Swing, The Coming of the United Religions (Grand Rapids: CoNexus Press, 1998), 12-13; Sally Mahé, “United Religion Initiative: Global Community Emerging,” Integral Review 8 (2012): $96-100$.

21 United Religions Initiative Archives, 1995-2013. Box 1, Folder 3, Articles about Swing and the United Religions Initiative, 1996-2000. (The boxes are quoted according to the guidelines of the respective archives.)

22 Speech by The Rt. Rev. William E. Swing, North American Interfaith Network Conference, Dallas, August 10, 1996.

23 United Religions Initiative Archives, 1995-2013. Box 1, Folder 3, Articles about Swing and the United Religions Initiative, 1996-2000, "The Rt. Rev. William E. Swing, 'Uniqueness of the United Religions."”

24 The most current figures for Cooperation Circles (CCs) in the URI include the following: African Continent: 145 CCs; Asia: 228 CCs; Europe: 46 CCs; Latin America and the Caribbean: 38 CCs; Southeast Asia and the Pacific: 37 CCs; North America: 62 CCs. 
engaging over 88 faith traditions and 84 countries. ${ }^{25}$ Most CCs function independently in their individual countries but in order to become part of the URI global structure, they are required to sign the Charter. Multiple global religious representatives serve as contributors and project affiliates for URI. Local and global interfaith leaders are also actively engaged with the organization.

What is unique about the structure of URI is its localized nature. URI projects are diverse and range from youth leader programs to peace initiatives, and many more, such as: interfaith solidarity networks, women's empowerment movements, civic engagement, environmental protection, and interfaith dialogue. Projects are context-sensitive and localized. This means that there is no singular reason why an organization chooses to become a URI member. Local needs determine the desire to participate in URI and each CC operates independently while under the URI organizational umbrella. The head office of the URI, based in San Francisco, offers support and training to CCs across the world and connects people with similar interests. The structure of the URI is thus fluid yet maintained through a sustained belief in the core values of the organization.

In this paper, I analyze the dialogical process involved in creating the URI Charter, particularly the Preamble, as well as relevant documents at the center of these developments. I argue that the Preamble marks a shift in the interreligious dialogue movement that is punctuated by the search for truly inclusive language. After the initial idea to create a United Religions, one of the first challenges Swing encountered was creating a Charter to reflect URI's values. He also wanted the Charter to encapsulate the theological and religious diversity of its supporters, the myriad social issues in need of redress, and define URI's role in the process. A draft committee was selected. Together, they worked to create a Charter that was inclusive of multiple, religious voices while remaining rooted in the core principles of URI. Because of a commitment to inclusive language, the Charter took almost three years to articulate.

During the Charter development, two dialogical strategies were introduced to URI that helped to articulate the values of the organization. The first strategy was introduced by David Cooperrider, an organizational behaviorist. Cooperrider's methodology, called Appreciative Inquiry (AI) focused on the concept of "sacred listening" for fostering interreligious engagement. A second methodology emerged through the work of Dee Hock, the founder of VISA. Hock introduced ‘Chaordic Organisation' which was a system based on democratic, non-hierarch-

25 At the time this book is going to press, the number of CCs worldwide has now reached one thousand. 
ical dialogue. I analyze further below these strategies to explore the dimensions and boundaries of inclusive language in the URI Charter. As I describe, these methodologies were the integral components for the development of this Charter. Utilizing these strategies enabled URI to engage in interreligious dialogue that was defined by inclusive language.

What emerges from this analysis is the distinct contribution of URI to the field of interreligious dialogue. I argue that URI created an environment were all peoples, religious, spiritual, or secular who shared their principles could participate equally. This is particularly illuminating for interreligious dialogue. As Netland and Knitter indicate, dialogue is often limited in size and scope. ${ }^{26}$ Ecumenical dialogue is restricted to Christian circles. And, often, 'interfaith' communities do not reach out to fundamentalist, extant, secular, atheist, or humanist adherents. ${ }^{27}$ In contrast, URI offered everyone an invitation to "co-create" the Charter. This is evidenced by Swing's effort to reach beyond interfaith and religious leaders to grass-roots activists, secularists, pantheists, Wiccans, and theosophists. In his commitment to interreligious dialogue, Swing opened the door to people who are not usually invited to the table; and, he opened the door wide. The commitment to interreligious dialogue was manifest during the Charter development. Each word was analyzed, edited, and reevaluated to ensure that no voice was marginalized or overlooked. For URI, this process of dialogue emerges as the foundational principle of true interreligious engagement, which is illuminating for both practitioners and academics in the field.

\section{Methodology and Analytical Sources}

For this project, I utilized qualitative analysis and focused on interpreting 'texts.' Often, 'texts' are limited to transcripts or notes but can also include pictures and images. The most relevant part of the Charter for the broader discussion of the interreligious dialogue movement is the emphasis on inclusive language. Therefore, I utilized meeting Minutes, notes, and transcripts that focused on the linguistic debates that occurred while the Charter was being formalized. Michael Quinn Patton argues that textual interpretation can never fully be judged as

26 Knitter, Jesus and the Other Names; Netland, Encountering Pluralism, 216-218.

27 Gerald Hall, "Interfaith Dialogue," in Dreaming the Land: Theologies of Resistance and Hope, eds. Hans-Georg Ziebertz and Friedrich Schweitzer (London: Transaction Publishers, 2007), 99101. 
'true' or 'false. ${ }^{28}$ Instead, 'texts' are negotiated among a community of interpreters in a particular context. ${ }^{29}$ This means that analyzing 'texts' has certain limitations for any researcher. From a hermeneutic perspective, a researcher tries to engage with 'text' in a non-judgmental manner with an acknowledgement that his or her own socio-historical 'context' is always part of the interpretive process. Therefore, two researchers with different histories could reach very distinct conclusions while analyzing the same 'texts.' This limitation is acknowledged by the present researcher.

In an effort to be 'unbiased', several archival sources were consulted to analyze the development of inclusive language in the Charter. The sources varied in size and scope. The URI archives include several kinds of 'texts': Swing's diaries and travel accounts, newspaper articles, correspondence from supporters and dissenters, meeting Minutes, speeches, and budget reports. Diaries and travel accounts provided a useful description of the socio-political environment into which URI emerged. Newspaper articles and correspondence from supporters and dissenters provided a broad range of criticisms of URI during its foundational period. These critiques are pertinent because they reveal how much opposition Swing faced from conservative Christian circles in the United States, among others. Through analyzing these documents, I argue that these events were integral to Swing's commitment to creating a Charter that was rooted in inclusivity and mutual respect.

Two books that are part of URI archival sources were also consulted for this project. The first book, the Coming of the United Religions is by Swing and delineates the theological commitments that inspired URI. He also writes with candor about the criticism and censure that URI received during its foundational period. The second book, Birth of a Global Community: Appreciative Inquiry in Action, was written by Charles Gibbs and Sally Mahe, two members of the URI team. Gibbs and Mahe describe in detail the initial difficulties over inclusive language that emerged during Charter development. This book also examines Appreciate Inquiry (AI), the primary dialogical methodology utilized in creating the Charter. Both books provide significant information for analyzing the structure and function of interreligious dialogue during the foundational period of URI.

The central methodology for this paper was the linguistic analysis of the Charter, particularly, the Preamble. The Preamble was the 'purpose statement' for the United Religions. It, therefore, had to answer many questions. What

28 Michael Quinn Patton, Qualitative Research \& Evaluation Methods (New York: Sage Publications, 2002), 114.

29 Patton, Qualitative Research, 114. 
was the concept of 'United Religions'? Who were the members? What were their religious, spiritual, and socio-political goals? Who was invited to participate and whose voices were absent? The draft committee hypothesized that diverse people and opinions would stimulate respectful dialogue and that this dialogue would lead to a Charter that was theologically and linguistically inclusive. The draft committee began working on the Charter in June 1997 and ensured that diversity was part of the development process. Scholars, writers, interfaith activists, developmental organizers, futurists, business consultants and multiple, religious adherents were invited to participate in the process.

In the next section, I describe how Swing first developed the idea to create a United Religions Initiative. Next, I describe the initial response to Swing when he decided to create a global interfaith organization. After this brief examination, I turn to an analysis of Appreciative Inquiry (AI), the first dialogical methodology that was utilized by URI in engaging fruitful interreligious dialogue. I then analyze a second dialogue strategy, Chaordic Organization. My analysis reveals how these two strategies functioned during the development of the URI Charter. Utilizing archival sources including meeting Minutes, transcripts, and notes, I provide salient examples of how language was amended to represent religious inclusivity and diversity.

\section{A Floating Vision: "Come, Let's Fly!"}

In 1993, Swing, the Episcopal bishop of California received an unusual phone call from the United Nations (U.N.). ${ }^{30}$ Swing was asked to host an interfaith ceremony at Grace Cathedral scheduled for June 1995 to honour the $50^{\text {th }}$ anniversary of the U.N. Charter. Because the U.N. Charter was originally signed in San Francisco, the city was a natural choice for the fiftieth-anniversary celebration. Grace Cathedral, with its diverse and socially active congregation, was also a poignant selection. Swing, a progressive Episcopalian was asked to create a liturgical service that was theologically inclusive and respectful of the representatives of the world religions who would attend the ceremony. ${ }^{31}$ The United Nations would

30 Katherine Marshall, Global Institutions of Religion: Ancient Movers, Modern Shakers (New York: Routledge, 2013), 141-142.

31 As a member of the Episcopalian Church, Swing was known for his progressive attitude towards gay and lesbian ordination as well as women's ordination. This ideology was largely favored in the Episcopal Church in the United States and was often critiqued by more conservative mainline Protestants who do not support female or gay and lesbian clergy. 
bring 183 ambassadors to San Francisco in honor of the $50^{\text {th }}$ anniversary; Swing was asked to gather the 'world religions."32

In his monograph, Swing writes that after agreeing to host the interfaith service, he was immediately "stirred, haunted, and convicted by one thought." 33 Swing was struck by the role of religion(s) in the socio-political engagement of the world. In his diary, Swing writes, "In the 50 years that the nations have gathered permanently and daily to strive for global good, the religions have not done the same. Here we are on the verge of global interfaith living and the religions still do not have the vision and the moral courage of the nations." 34 This led Swing to ask a series of questions. Why were nations so different from religions? Did religions lack the moral courage to strive for the global good? Did the teleology of religions include the global good? Captivated by these ideas, Swing awoke the next day with a newfound sense of determination. Swing decided to create an organization that would change the role of religion(s) in the world. He contemplated calling this organization the "United Religions" which would, "in appropriately spiritual ways, parallel the United Nations."35

Inspired by his conviction, Swing began to lay roots for the United Religions almost immediately. He gathered the names of international interfaith leaders and scheduled a conference in New York on 21 June 1993. Following the recommendations of these interfaith leaders, Swing conducted an Interfaith Youth Conference in June 1995 for 200 young people of 46 religions. Prominent speakers included Desmond Tutu and W.D. Mohammed. ${ }^{36}$ A day after the conference, the interfaith service for the $50^{\text {th }}$ anniversary of the U.N. Charter was held at Grace Cathedral in 1995. The liturgy took Swing almost two years to prepare.

32 United Religions Initiative Archives, 1995-2013. URI General History, Box 1, Folder 1, General History and Descriptions of the URI, 1995-1997; Box 1, Folder 2, "Interfaith Service for the $50^{\text {th }}$ Anniversary of the United Nations Charter, 1995.”

33 United Religions Initiative Archives, 1995-2013. URI General History, Box 1, Folder 1, General History and Descriptions of the URI, 1995-1997, Speech by The Rt. Rev. William E. Swing, North American Interfaith Network Conference, Dallas, August 10, 1996; This story is also paraphrased in Swing, The Coming of the United Religions, 12-13.

34 Speech by The Rt. Rev. William E. Swing, North American Interfaith Network Conference, Dallas, August 10, 1996.

35 Speech by The Rt. Rev. William E. Swing; URI General History, Box 1, Folder 4, "Swing’s Pilgrimage Around the World,” 1996; URI General History, Box 1, Folder 5, “Articles on 's Pilgrimage from San Jose Mercury News," 1996.

36 URI General History, Box 1, Folder 20, "UN50 Interfaith Youth Conference: Correspondence, 1993-1995”; URI General History, Box 1, Folder 21, “UN50 Interfaith Youth Conference: Correspondence, 1995”; URI General History, Box 1, Folder 22, “UN50 Interfaith Youth Conference invitations 1994-1995.” 
In September 1995, Swing presented his idea of a United Religions to the U.N. in New York. A month later, he introduced his concept in Beijing, Nanjing, Shanghai, Hong Kong, and Taiwan. On each occasion, Swing met with resounding support. This bolstered his resolve and in 1996, Swing embarked on a journey around the world to meet with religious leaders and discuss the formal establishment of the United Religions. ${ }^{37}$

The world tour began with the Mar Thoma Church in Kerala, India. ${ }^{38}$ Swing then met with Mother Teresa in Kolkata, discussed his ideas with the Dalai Lama, and engaged Baha'i, Sikh, Jain, Muslim, and Zoroastrian religious leaders in India. ${ }^{39}$ He then traveled to Pakistan and met with Javid Iqbal, various Muslim religious leaders, writers and Supreme Court Justices. ${ }^{40}$ Next, he went to Egypt and met with Orthodox Coptic Pope, Shenouda III and the Grand Mufti, Mohammed Syed Tantawi. ${ }^{41}$ In Jerusalem, Swing met with Rabbi Mordechai Peron. In Jordan, he discussed the United Religions with the Crown Prince and the Ecumenical Patriarch Bartholomew in Istanbul. ${ }^{42}$ Next, he went to the World Council of Churches (WWC). After meeting with Hans Küng in Tubingen, Swing discussed his ideas with Cardinal Arinze and Pope John Paul II in Rome. ${ }^{43}$ After a brief meeting with the Archbishop of Canterbury, Swing went east to Japan and Korea. It was a year of high-level dialogue and the "floating vision" of the United Religions was met with both support and encouragement. ${ }^{44}$

In 1996, the United Religions established its first physical office through monetary donations from supporters in San Francisco and across the world. A staff of 5 full-time employees and 37 volunteers were ready to actualize the

37 URI General History, Box 1, Folder 4, "Swing’s Pilgrimage Around the World,” 1996; URI General History, Box 1, Folder 5, "Articles on 's Pilgrimage from San Jose Mercury News, 1996. 38 The Mar Thoma Church in Kerala, South India is the Syrian Church traditionally believed to be founded by Saint Thomas, one of the 12 apostles of Jesus of Nazareth. The Church defines itself as "Apostolic in origin" and tradition suggests it was established in 52 CE.

39 URI History, Box 1, Folder 1, "Writings about URI by Swing and others, 1995-2005”; URI History, Box 1, Folder 32-A, "Writings about URI by Swing and others, 1995-2005”; URI History, Box 1, Folder 34, Oxford Talk: "Interfaith Achievements? Initiatives Around the World, 1996."

40 Javid Iqbal is the son of poet laureate and philosopher Mohammed Iqbal.

41 URI History, Box 1, Folder 1, "Writings about URI by Swing and others, 1995-2005"; URI History, Box 1, Folder 32-A, "Writings about URI by Swing and others, 1995-2005”; URI History, Box 1, Folder 34, Oxford Talk: "Interfaith Achievements? Initiatives Around the World, 1996.” URI History, Box 1, Folder 38, "Swing's travels to visit World Religious Leaders, 1996."

42 URI History, Box 1, Folder 38, "Swing’s travels to visit World Religious Leaders, 1996."

43 URI History, Box 1, Folder 38, "Swing’s travels to visit World Religious Leaders, 1996."

44 URI History, Box 1, Folder 40, "Responses from religious leaders, 1996.” 
"floating vision." 45 First, the staff worked to complete the 501 (c) 3 application which enables non-profit, tax-exempt organizations to legally function in the United States. Next, they designed a website. With these changes, the United Religions entered the development stage. ${ }^{46}$ In June 1996, at the first United Religions Summit, in his opening speech, Swing said, "Today indeed is a special moment. Credulity trembles. And delirious hope gasps for a first breath. An entire new life for the world beckons us to step ahead. ${ }^{\text {47 }}$ He reminded the crowd of his "floating vision" that had now been shared with international religious and political leaders. ${ }^{48}$ He next issued the following invitation:

At the first of this century, there was a time when human beings knew in their bones that we should fly. So all kinds of people glued feathers to their arms, climbed to the top of the barn, began flapping, and jumped off. And sure enough, right around there, we learned to fly. I don't mind standing in front of you today smelling of feathers and sticking with glue. I'll tell you right now, I'm jumping. This Summit comes down to one invitation to you around the creation of the United Religions. 'Come, let's fly. 49

\section{The Dialogue Begins: Challenges of Syncretism, Inclusivism, and Proselytizing}

Within weeks of establishing a physical presence in San Francisco, the negative responses came pouring in Swing's office. ${ }^{50}$ In contrast to the warm support he encountered overseas, in the United States, conservative Christians were less keen on the United Religions. In his book, Swing writes, "Placard carrying folks picketed us. One group wrote that I was the anti-Christ." ${ }^{21}$ Journalists noted that many conservative Christians accused URI of being a syncretic organ-

45 URI History, Box 1, Folder 32-A, "Writings about URI by Swing and others, 1995-2005" "United Religions Summit, June 24-28, 1996, Opening Speech by The Rt. Rev. William E. Swing.” 46 URI History, Box 1, Folder 32-A, "Writings about URI by Swing and others, 1995-2005" "United Religions Summit, June 24-28, 1996, Opening Speech by The Rt. Rev. William E. Swing." 47 URI History, Box 1, Folder 32-A, "Writings about URI by Swing and others, 1995-2005" "United Religions Summit, June 24-28, 1996, Opening Speech by The Rt. Rev. William E. Swing.” 48 URI History, Box 1, Folder 32-A, "Writings about URI by Swing and others, 1995-2005" "United Religions Summit, June 24-28, 1996, Opening Speech by The Rt. Rev. William E. Swing.” 49 URI History, Box 1, Folder 32-A, "Writings about URI by Swing and others, 1995-2005" "United Religions Summit, June 24-28, 1996, Opening Speech by The Rt. Rev. William E. Swing.” 50 The United Religions established its first physical office in the Presidio, a former military base in San Francisco which is now part of the Golden Gate National Recreational Area.

51 Swing, The Coming of the United Religions, 19-20. 
ization. $^{52}$ Newspaper articles claimed that many Christians were offended by Swing's inclusive attitude. For example, the U.N. interfaith service at Grace Cathedral was heavily critiqued because of Swing's interreligious attitude. Some argued that during this service, "prayers, chants and incantations were offered to a dozen deities", which offended the sacredness of the Church. ${ }^{53}$ Others said the United Religions was guilty of promoting a "one-faith fits all mentality." ${ }^{4}$ In his book, Swing writes that he was accused of creating a religious "conspiracy which aims at joining with the United Nations to form a single world government and a single world religion." 55

Some observers also critiqued Swing's open-door policy towards diverse religious and spiritual communities. One particular critic, Lee Penn, was most vocal in his contempt for URI. Penn argued that Swing had supporters among extant and esoteric groups that were dangerous to the Christian faith. ${ }^{56}$ Indeed, the United Religions did find resounding support among New Agers, Wiccans and theosophists, including the Rudolph Steiner Foundation. ${ }^{57}$ When the Rudolph Steiner Foundation, in particular, pledged its financial support, it invited the ire of conservative Christians. Wiccans, New Agers, and Pantheists were also anathema to many conservative Christians and secured their distrust of URI and Swing. A further rift was created by Swing's unwavering support of the lesbian, gay, bisexual, transgender and queer (LGBTQ) community in San Francisco. ${ }^{58}$ This coupled with the bishop's support of gay ordination led many conservative

52 Trudi Lawrence, Theosophy, Ecology, \& Pan-Religion: https://www.traditioninaction.org/ History/G_011_PanReligion.html (accessed: 24.5.2020).

53 URI General History, Box 1, Folder 4, “Swing’s Pilgrimage Around the World, 1996; URI General History, Box 1, Folder 5, “Articles on Swing’s Pilgrimage” from San Jose Mercury News, 1996. Trudi Lawrence, "Theosophy, Ecology, \& Pan-Religion” Tradition in Action, January 11, 2011. 54 URI History, Box 1, Folder 32-A, "Writings about URI by Swing and others, 1995-2005"; "Bridge to the One-World Religion: The Foundation" Times Digest and Newsbytes, February, 2000.

55 Swing, The Coming of the United Religions, 60.

56 URI History, Box 1, Folder 32-A, “Writings about URI by Swing and others, 1995-2005”; URI History, Box 1, Folder 12, "Negative Responses to URI, 1996-2000, Lee Penn, "Midwives of a Common Good: The Myriad Friends of the United Religions Initiative", Touchstone: A Journal of Mere Christianity, June, 2000.”

57 URI History, Box 1, Folder 32-A, "Writings about URI by Swing and others, 1995-2005”; URI History, Box 1, Folder 12, "Negative Responses to URI, 1996-2000, Lee Penn, "Midwives of a Common Good: The Myriad Friends of the United Religions Initiative”, Touchstone: A Journal of Mere Christianity, June, 2000."

58 LGBTQ is the acronym most commonly used in the United States to refer to Lesbian, Gay, Bisexual, Transgender, and Queer/Questioning community. 'Questioning' refers to people who are unsure about their gender or sexual orientation. 
Christians to conclude that the United Religions was itself a deviant organization.

A second issue during this foundational period stemmed from Swing's commitment to inclusivity. While tolerance of the 'other' was respected in the Christian tradition, inclusivism brought with it some cumbersome theological baggage. While ecumenical dialogue was valued, interreligious inclusivism heightened fear and suspicion. ${ }^{59}$ There was a notion that inclusivism had the potential to gloss over Christian 'truth claims' including the particularity of Christ. This indicates, as Netland suggests, that for many Christians, interreligious dialogue had boundaries. The general complaint against Swing was that he was too interreligious. Swing's ‘interfaith-ism' was construed as a dismissal of Christian doctrine and ecumenism. ${ }^{60}$ Further, engaging 'interfaith-ism' so inclusively was interpreted as a disregard for orthodoxy. As Swing reports in his book, some thought he "was the anti-Christ." ${ }^{1}$ This crucial point proved insurmountable for many conservative Christians and bolstered their dismissal of URI.

In his monograph, Swing relates an episode when his personal conviction to pluralism and inclusivity were virulently rejected. Swing was invited to participate in a long-distance radio program. The interviewer asked him whether there was only one way to God. Swing replied that there were many distinct ways to reach/see God, for example, "in the birth of the child, in a sight of nature, in a piece of music, in an enduring relationship." 62 The bishop reports that his response created such consternation and caused the interviewer to "scream so loudly that the radio station insisted he come back the next day and apologize."63 The source of this outrage can be traced to a feeling of betrayal among particular Christians who held the veracity of Christ and its source, the

59 URI History, Box 1, Folder 32-A, “Writings about URI by Swing and others, 1995-2005”; URI History, Box 1, Folder 12, "Negative Responses to URI, 1996-2000, Lee Penn, "Midwives of a Common Good: The Myriad Friends of the United Religions Initiative", Touchstone: A Journal of Mere Christianity, June, 2000.”

60 URI History, Box 1, Folder 32-A, "Writings about URI by Swing and others, 1995-2005”; URI History, Box 1, Folder 12, "Negative Responses to URI, 1996-2000, Lee Penn, "Midwives of a Common Good: The Myriad Friends of the United Religions Initiative”, Touchstone: A Journal of Mere Christianity, June, 2000."

61 Swing, The Coming of the United Religions, 19-20.

62 Swing, The Coming of the United Religions, 60; URI History, Box 1, Folder 32-A, "Writings about URI by Swing and others, 1995-2005”; URI History, Box 1, Folder 8, "Writings by Swing about the URI, 1996-2005."

63 Swing, The Coming of the United Religions, 60; URI History, Box 1, Folder 32-A, "Writings about URI by Swing and others, 1995-2005"; URI History, Box 1, Folder 8, "Writings by Swing about the URI, 1996-2005.” 
Bible, as a singular truth that was irreproachable. For these Christians, the notion that one could reduce revelation to the "birth of a child or a piece of music" was both heretical and discomforting.

A further issue related to biblical truth(s) emerged when Swing expressed his views on exclusive religious claims. Swing firmly believed that exclusivity had the potential to create disagreement and contention among different religions. While not against exclusive truth claims, Swing demarcated clear boundaries about their function in URI. In his book, Swing argues, "the absolute exclusive claims of each [religion] will be honored but an agreed upon neutrality will be exercised in terms of proselytizing, condemning, murdering, or dominating. These will not be tolerated in the United Religions zone."64 There was no internal debate in the United Religions on proselytizing; it was simply not part of the ethos of the organization. This commitment to inclusivity was interpreted by conservative Christians as an affront to evangelism. Despite these difficulties, Swing forged ahead bolstered by a commitment to create a global interfaith organization.

\section{The Dialogue Develops: Introducing Appreciative Inquiry (AI)}

A key issue in interreligious dialogue often relates to who is invited to participate in 'dialogue.' ${ }^{65}$ Religion scholar Leonard Swidler argues that: "It is important that interreligious, inter-ideological dialogue not be limited to official representatives or even to the experts in the various traditions, although they have irreplaceable roles to play in dialogue."66 This became pertinent within a few months of the establishment of URI when Swing and key members of his team focused on creating a Charter. A host committee was selected and began compiling a list of participants to invite to a Charter Summit. The list reflected religious inclusivity and included Brahma Kumaris, Buddhists, Christians, Hindus, Jews, Muslims, Native Americans, Sufis, secularists, and humanists. Positive responses were received. ${ }^{67}$ Budget and lodging issues soon surfaced. The initial idea was to host the Summit at the Presidio in San Francisco, a former military base where URI had secured their office. This decision proved both impractical and expen-

64 Swing, The Coming of the United Religions, 31. 65 Swing, The Coming of the United Religions, 31. 66 Swing, The Coming of the United Religions, 12. 67 Swing, The Coming of the United Religions, 18. 
sive. ${ }^{68}$ Eventually, the host committee selected the Fairmont Hotel where the original U.N. Charter was signed as the location for the Summit on June 24, 1996.

Once the logistics were arranged, there still remained the daunting task of constructing a meaningful dialogue with an ethnically, culturally, and religiously diverse group of people.

This is often a practical difficulty in the field of interreligious dialogue. ${ }^{69}$ To structure the dialogue, the host committee raised several questions to guide Summit participants. Would the United Religions have a logo? What would the letterhead and logo look like? Would it feature words or just symbols? In their book, Gibbs and Mahe, two URI team members argue that host committee viewed its contributions to the Charter development as "an act of service" and wanted to guide the process with trying to "control the forum."70 As such, the host committee was conceptualized as a "midwife" or "scaffolding" which would dismantle after the Charter was formulated. ${ }^{71}$ Their main concern, however, was to structure an effective and constructive dialogue between Summit attendees.

Practitioners of interreligious dialogue argue that there are many forms of 'dialogue.' For example, Swidler argues that: "While the intellectual and verbal communication is indeed the primary meaning of dialogue, if the results therefrom do not spill over into the two areas of action and spirituality, it will have proved sterile."72 This quickly became a concern for the host committee. Gibbs and Mahe describe that initial Charter development sessions had a serious lack of cohesion. Mahe writes that the first discussions over letterhead, logo, and language often "plunged the group into a swirling chaos of seemingly competing visions and values." 73 These issues were punctuated because many of the participants had varying degrees of interfaith and organizational experience. "Some brought deep experience of interfaith work; some, deep experiences of exclusion; some, fervor for the cause but no real interfaith experience or sensitiv-

68 Charles Gibbs and Sally Mahe, Birth of a Global Community: Appreciative Inquiry in Action, (San Francisco: Lakeshore Communications, Inc, 2004), 25.

69 Leonard Swidler, Khalid Duran, and Reuven Firestone, Trialogue: Jews, Christians, and Muslims in Dialogue, (New London: Twenty-Third Publications, 2007), 11.

70 Swidler et al., Trialogue: Jews, Christians, and Muslims, 11.

71 Swidler et al., Trialogue: Jews, Christians, and Muslims, 11.

72 Swidler et al., Trialogue: Jews, Christians, and Muslims, 14.

73 Charles Gibbs and Sally Mahe, Birth of a Global Community: Appreciative Inquiry in Action, (San Francisco: Lakeshore Communications, Inc, 2004), 15. 
ity." "74 Each step was tentative because the emphasis was on inclusivity among a religiously diverse community.

As the host committee was deliberating the best methodological approach to the Summit dialogue, a solution was presented by David Cooperrider, a professor of Organizational Behavior. Cooperrider was the creator of a developmental methodology called, Appreciative Inquiry (AI). The foundational structure of AI is based on democracy and conceptualized around the practice of "sacred listening." ${ }^{75}$ AI has four components: Discovery, Dream, Design, and Destiny. ${ }^{76}$ This "4-D process" created the building blocks for "sacred listening." Hence, the process was immersive but not coercive. In other words, this was a true 'dialogue' where each participant was a "co-creator" in the process. Struck by the structure of this method, URI adopted AI as their dialogical strategy for the Summit. ${ }^{77}$ At the Summit, 55 people assembled in the Fairmont Hotel including religious adherents, futurists, interfaith activists, philanthropic consultants, scholars, and leaders of various NGOs. ${ }^{78}$ Conversations were framed through AI. First, questions focused on part one of the 4-D process-Discovery. This dialogue centered on participants 'discovering' each other through "Appreciative interviews."79 These interviews explored individual goals and served to bring diverse people closer to each other through "sacred listening."

After completing the first part of 'Discovery', participants focused on "Dream." Gibbs and Mahe write that some conceived of the United Religions as the spiritual counterpart of the United Nations with a "Bill of Spiritual

74 Gibbs and Mahe, Birth of a Global Community: Appreciative Inquiry in Action, (San Francisco: Lakeshore Communications, Inc, 2004), 15; URI General History, Box 2, "Appreciative Inquiry, 1997-2001”; URI General History, Box 2, “Organisational Design Team, 1997-1999.”

75 Gibbs and Mahe, Birth of a Global Community, 18.

76 Gibbs and Mahe, Birth of a Global Community, 29. The authors describe the 4-D process in the following way: "Discovery calls people to share with each other what is most deeply meaningful to them, to appreciate the gifts they and others bring, and to cocreate a share sense of historical trends. Dream invites people to envision a positive future built of experiences of the past, a future where the world's religions are working for global change. Design challenges people to engage wisdom from related fields; to develop consensus around common themes such as the organisation's mission, vision, values, structure, and actions; and to create plans for future work. Destiny invites people individually and collectively to make specific commitments to work toward the realization of their dreams and plans.”

77 Gibbs and Mahe, Birth of a Global Community, 31.

78 Gibbs and Mahe, Birth of a Global Community, 31.

79 Gibbs and Mahe, Birth of a Global Community, 35; URI General History, Box 1, Folder 42, "United Religions Summit, 1996; URI General History, Box 1, Folder 43, "Summit Register and Agenda, 1996; URI General History, Box 1, Folder 44, "Summit press packet, 1996; URI General History, Box 1, Folder 45, “Conference Summary, 1996. 
Rights." ${ }^{80}$ Meanwhile, others dreamed of mobilizing people and nations for justice and peace. ${ }^{81}$ The third ' $\mathrm{D}$ ' in the “4-D" of AI was "Design.” During this section, participants mapped an organizational structure and generated guidelines for URI. In the fourth AI segment, "Destiny", participants described their future vision of URI. During this process, Gibbs and Mahe note that Summit attendees decided three things. First, URI would actively engage grassroots people and projects. Second, they would welcome people of all spiritual backgrounds and third, focus on social justice. Over the next three years, the United Religions held more summits to define their ideology and create an inclusive Charter.

As this brief description reveals, this Summit resonated with many issues that concern interreligious dialogue practitioners today. Namely, how a 'dialogue' is structured and framed. What is distinct about AI methodology is "sacred listening." Swidler argues that this spiritual dimension of interreligious dialogue is often overlooked to its detriment. "Because religion is not something of the head and the hands, but also of the heart-of the whole human being-our encounter with our partner must also eventually include the depth or spiritual dimension." ${ }^{83}$ This observation is precisely why AI was so successful. Therefore, the "4-D" process enabled participants from diverse traditions and cultures to 'Discover' and 'Dream' together and then 'Design' the 'Destiny' of URI. Therefore, people were not 'observers' but rather "co-creators" in Charter development. In this way, the Summit engendered a cohesive 'dialogue' instead of multiple 'monologues.' As I describe in the next section, AI was further strengthened through the introduction of another methodology called Chaordic Organization.

\section{The Dialogue Expands: Chaordic Organization and the Charter}

In June 1997, the United Religions convened a Global Summit to begin officially drafting a Charter. Three months after the Global Summit, URI staff was joined by Dee Hock, the founder of VISA. Hock was the creator of a developmental strategy called "Chaordic organizing." 'Chaordic' is a fusion of the words, chaos and order. This developmental strategy joined together two competing visions: the

80 Gibbs and Mahe, Birth of a Global Community, 35.

81 Gibbs and Mahe, Birth of a Global Community, 35

82 Leonard Swidler, Khalid Duran, and Reuven Firestone, Trialogue: Jews, Christians, and Muslims in Dialogue (New London: Twenty-Third Publications, 2007), 14.

83 Swidler et al., Trialogue: Jews, Christians, and Muslims, 14. 
chaos of unlimited contributions and the order of structured principles. ${ }^{84}$ In other words, Chaordic Organization promotes an open dialogical process, which is non-hierarchical and co-creative. ${ }^{85}$ As Hock described this strategy, key members of URI found it was a perfect complement to AI dialogue. Gibbs and Mahe write that Chaordic Organization was coupled with AI and emerged as a central component of the Charter process.

The ultimate goal of the Chaordic organization was the creation of a Charter that reflected inclusivity. As such, the draft committee encouraged participants to express their critiques, however small. No voice was marginalized, and no opinion excluded. Gibbs and Mahe describe this editing process in their book. Several archival sources including meeting Minutes and notes also indicate the re-writing process. These sources do not mention people by name, but they do record objections to a particular language. The original Preamble of the Charter stated:

We, people of many faiths, called by our traditions to compassion in response to the suffering of humanity and the crises, which endanger our Earth community, wish to create a permanent forum where we gather in mutual respect, dialogue, and cooperative action to foster peace and the flourishing of all life. ${ }^{86}$

One of the first critiques centered on the opening sentence, "We, people of many faiths." Gibbs and Mahe note that one critique noted that "many faiths" implied that some faiths were not invited to URI. This raised an issue that became a prevalent theme during the establishment of the organization: Who could participate in the United Religions? As the United Religions was centered on inclusivity, the committee decided to revise the opening statement. The new statement said, "We, people of diverse faiths."

In this manner, the incorporation of Chaordic Organization with AI "sacred listening" ensured that all critiques, regardless of size were addressed. Through this process, each line of the Preamble was critiqued. The second line of the Pre-

84 Gibbs and Mahe, Birth of a Global Community, 129; URI General History, Box 2, "Appreciative Inquiry, 1997-2001”; URI General History, Box 2, “Organisational Design Team, 1997-1999.” URI General History, Box 2, “Chaordic Design Work, 1997-1999.”; URI General History, Board of Directors/Global Council, Box 3, "URI Board Meetings"; URI General History, Board of Directors/ Global Council, Box 3, “URI Corporate Minutes.”; URI General History, Board of Directors/Global Council, Box 3, "URI Transitional Advisory Group, 1999-2000.”

85 Gibbs and Mahe, Birth of a Global Community, 129.

86 Draft Preamble-Affirmed at Global Summit, June 26, 1998. URI General History, Box 1, Folder 18, "Preamble, Purpose, and Principles, 1999"; URI General History, Box 1, Folder 19, "Draft Charters, 1999”. 
amble stated: "called by our traditions to compassion.” Meeting Minutes indicate that the word "traditions" was not perceived as being adequately inclusive. This is because it disregarded 'culture and values' that might not emerge from religious traditions. ${ }^{87}$ Some participants noted that many people uphold 'values' instead of 'traditions.' While the former is more inclusive, the latter has a historical connection to 'religion.' 88 Archival notes indicate that the word 'traditions' had the potential to exclude supporters who do not prescribe to a religion but still share the core values of URI. The language was soon amended. The revised text of the Preamble stated: "We, people of diverse faiths, called by our values and traditions to compassion." 89

The second line of the Preamble elicited further debate because of the implicit tone of negativity in the language. The second line stated, "in response to the suffering of humanity and the crises which endanger our Earth community." Participants critiqued the word "crises" so early in the Charter. If the United Religions was going to inspire change; where was the evidence of hope? Some motioned to remove the word "crisis", however, this was dismissed. This is because the foundational theory of URI was that the world was in crisis. ${ }^{90}$ Poverty, alienation, marginalization, and oppression were part of socio-political reality. ${ }^{91}$ As Swing notes in his book, this was not debatable. ${ }^{92}$ What needed clarification was the role of URI in these crises. The linguistic challenge was to strike a balance between despair and hope. ${ }^{93}$ After much discussion, a revision was proposed. The new text stated: "in response to the suffering of humanity and the crises which endanger our Earth community and to the rising hopes of humanity." ${ }^{\text {"4 }}$ This revised language struck the right tone between reality and hope.

As the dialogical process continued, AI methodology and the 4-D model of Discovery, Dream, Design, and Destiny was more crucial to the revision process.

87 URI General History, Box 1, Folder 19, “Draft Charters, 1999”, “United Religions Initiative Proposed Revised Draft Charter, May 20, 1999.” Emphasis Added.

88 URI General History, Box 1, Folder 19, "Draft Charters, 1999”, "United Religions Initiative Proposed Revised Draft Charter, May 20, 1999."

89 URI General History, Box 1, Folder 19, "Draft Charters, 1999”, “United Religions Initiative Proposed Revised Draft Charter, May 20, 1999.”

90 URI General History, Box 1, Folder 19, "Draft Charters, 1999”, "United Religions Initiative Proposed Revised Draft Charter, May 20, 1999.”

91 Swing, The Coming of the United Religions, 76.

92 Swing, The Coming of the United Religions, 76.

93 URI General History, Box 1, Folder 19, "Draft Charters, 1999”, "United Religions Initiative Proposed Revised Draft Charter, May 20, 1999."

94 URI General History, Box 1, Folder 19, “Draft Charters, 1999”, “United Religions Initiative Proposed Revised Draft Charter, May 20, 1999.” Emphasis added. 
During the initial Global Summit, Discovery, Dream, Design, and Destiny focused on the future vision(s) for URI. However, during the Charter development, 'Discovery' centered on 'locating' and 'creating' inclusive language. ${ }^{95}$ The committee believed that this language would enable the accurate reflection of the 'Dream (s)' of the United Religions. Engaging the 'Design' and 'Destiny' of the Charter led the draft committee to engage the 'text' and 'context' of the Charter. Meeting Minutes indicate that the Charter had to include those who were unable to participate because of economic, religious, political, and social restrictions. ${ }^{96}$ As such, the draft committee cultivated a keen awareness of absentee voices and their role as silent co-creators of the Charter. ${ }^{97}$

A refined awareness of absence and presence meant the need to further hone inclusive language. A new linguistic problem emerged with the second line of the Preamble, "in response to the suffering of humanity and the crises which endanger our Earth community and to the rising hopes of humanity."98 Gibbs reports this issue was connected to capitalizing the word "Earth." Critics argued that capitalizing "Earth" was not inclusive because it privileged Inuit traditions. ${ }^{99}$ Others suggested that capitalizing "Earth" was the same as including 'Jesus Christ' or 'Allah' in the Preamble. ${ }^{100}$ Some asserted that the Charter should not privilege any tradition or culture and remain theologically neutral. Gibbs notes that in contrast, a few raised a counter-argument that capitalizing "Earth" indicated a profound "sense of interconnectedness and a sense of accountability" that belied the boundaries of any tradition. ${ }^{101}$ Eventually, the word "Earth" remained capitalized because of an emergent need to recognize the human impact on the planet. ${ }^{102}$

Through AI and Chaordic Organization, each part of the Preamble was thoroughly analyzed for inclusive language. For example, the third sentence of the Preamble stated: "We affirm that, in spite of differences of practice or belief,

95 Gibbs and Mahe, Birth of a Global Community, 60-107.

96 URI General History, Box 1, Folder 19, "Draft Charters, 1999”, "United Religions Initiative Proposed Revised Draft Charter, May 20, 1999.”

97 URI General History, Box 1, Folder 19, "Draft Charters, 1999”, "United Religions Initiative Proposed Revised Draft Charter, May 20, 1999.”

98 URI General History, Box 1, Folder 19, “Draft Charters, 1999”, “United Religions Initiative Proposed Revised Draft Charter, May 20, 1999.” Emphasis added.

99 Charles Gibbs, “Overview of Work on Charter/Detailed Description of Purpose Statement Development from June 1999 Summit to Present 10/11/99.” URI General History, Box 1, Folder 19, "Draft Charters, 1999."

100 Gibbs, "Overview of Work".

101 Gibbs, "Overview of Work".

102 Gibbs, "Overview of Work". 
our faiths call us to care for one another." While this language might appear benign to outsiders, the words "in spite" created much consternation. ${ }^{103}$ Meeting notes suggest that some participants thought "in spite" was an acceptable phrase. ${ }^{104}$ However, others pressed for a better way to affirm religious diversity. The draft committee soon offered a revision, which stated: "While honoring our differences of practice and belief, we affirm that our faiths call us to care for each other."105 The omission of the words "in spite" created space to honor religious diversity as a defining principle of URI. Further, the revised language also highlighted that the connective thread among disparate religions was the affirmation to care for each other.

Other sections of the Preamble raised concerns about the role of URI in peace-building. The original Preamble stated: "We unite to pray for peace, to practice peacemaking, to be a force for healing, and to provide a safe space for conflict resolution." Some participants raised concerns about the ability of URI to "provide a safe space" for people in conflict zones. Was this a reasonable goal or an impossible promise? How would such promises become actualized in the geopolitical context? After several revisions, the language was amended. The new statement read: "We unite to build cultures of peace. We unite to build a safe place for conflict resolution and healing."106 The draft committee commented in the margins, in handwritten notes, that this version identified a more achievable goal. ${ }^{107}$ The emphasis was on building sustainable structures for future peacebuilding efforts. ${ }^{108}$ This amendment also indicates that URI was in the process of identifying institutional boundaries.

In this early stage, while all aspects of the Charter were open for discussion and debate, it is significant to note that some parts of the Preamble remained unchanged. For example, the original draft stated; "We believe that the wisdom of our religious and spiritual traditions should be shared for the health and well-

103 URI General History, Box 1, Folder 19, "Draft Charters, 1999" "United Religions Initiative Proposed Revised Draft Charter, May 20, 1999.” Emphasis added.

104 URI General History, Box 1, Folder 19, "Draft Charters, 1999" "United Religions Initiative Proposed Revised Draft Charter, May 20, 1999.”

105 URI General History, Box 1, Folder 19, "Draft Charters, 1999" "United Religions Initiative Proposed Revised Draft Charter, May 20, 1999."

106 URI General History, Box 1, Folder 19, "Draft Charters, 1999” "United Religions Initiative Proposed Revised Draft Charter, May 20, 1999.” Emphasis added.

107 URI General History, Box 1, Folder 19, "Draft Charters, 1999" "United Religions Initiative Proposed Revised Draft Charter, May 20, 1999."

108 URI General History, Box 1, Folder 19, "Draft Charters, 1999" "United Religions Initiative Proposed Revised Draft Charter, May 20, 1999.” 
being of all."109 This language, at least in the early sessions, remained the same. This is pertinent because this statement succinctly states the primary function and purpose of URI. The core values of people engaged in the Charter process was the belief that religions should be shared with others. In addition, as Swing writes in his book, there was the theological commitment that religion(s) was capable of providing hope and creating peace. ${ }^{110}$ That such a diverse group could agree on this dimension of religious faith is perhaps the reason that URI membership continued to grow in subsequent years.

As membership expanded, so did reflections on the Charter. Although people who joined the organization were from increasingly diverse traditions and cultures, the uniting theme was a belief that religion has the power to heal. In the final articulation of the Preamble, the draft committee included the following declaration: "We believe that our religious, spiritual lives, rather than dividing us, guide us to build community and respect for one another.” For URI members, this statement captured the deepest truth: religious and spiritual commitments are rooted in social justice and human dignity. This was further clarified in the final version of the Preamble, which states; "We unite to use our combined resources only for nonviolent, compassionate action, to awaken to our deepest truths, and to manifest love and justice among all life in our Earth community." 111

In his analysis of interreligious dialogue, Swidler notes that an effective dialogue has the potential to create transformation for participants. "In the very process of responding to the questions of our partners, we look into our inner selves and into our traditions in ways that we perhaps never would have, and thus come to know ourselves as we could not have outside the dialogue."112 What is distinct about URI is that this 'interreligious dialogue', which focused on Charter development, occurred with religious and non-religious people, as evidenced by Summit participants, and through the utilization of AI and Chaordic Organization, two different behavioral and business strategies. The notion that URI utilized two theories from outside the field of interreligious dialogue is particularly significant to the field of interreligious dialogue itself, for two reasons. First, it is a testament to the methodological inclusiveness of URI. Second, it enabled this organization to engage in deep self-reflection. The notion of self-

109 URI General History, Box 1, Folder 19, "Draft Charters, 1999” "United Religions Initiative Proposed Revised Draft Charter, May 20, 1999.”

110 Swing, The Coming of the United Religions, 76.

111 URI General History, Box 1, Folder 19, "Draft Charters, 1999" "United Religions Initiative Proposed Revised Draft Charter, May 20, 1999.”

112 Swidler et al., Trialogue: Jews, Christians, and Muslims, 15. 
reflection is one aspect of interreligious dialogue that Swidler particularly values. He argues that: "If we are not willing to look self-critically at our own and our tradition's position on a subject, the implication clearly is that we have nothing to learn from our partner." ${ }^{113}$ As this analysis depicts, URI was not afraid to engage self-critically with their organization or tradition. Hence, the Charter that emerged was the result of an effective and transformative dialogue.

The URI Charter was formally signed on 26 June 2000 after almost three years of revisions. The developmental strategies of AI and Chaordic Organization were not abandoned once the Charter was signed. Instead, these dialogical models continue to inform the structure and growth of URI. Choardic Organization enables Cooperation Circles (CCs) all over the world to work independently in their local contexts while remaining rooted in the principles of the Charter. Further, AI methodology and "sacred listening" continue to influence URI as it expands its reach. For the United Religions, AI enables true empathy with the 'Other', the less fortunate, the marginalized and the voiceless. As Swing indicates many times, that the world is in crisis is not debatable. ${ }^{114}$ What is under negotiation is URIs role in the process. While URI is active throughout the world, the uniting force of the global community is the Charter. Therefore, the only formal requirement for membership in the URI is to sign the Charter. And each year, membership continues to grow.

\section{The United Religions Initiative: A Restless, Young Voice}

Dialogue is not a new phenomenon. People and religions have always engaged in some form of dialogue. As interreligious scholars and theologians indicate, dialogue is not always inclusive and affirming. The history of the interreligious dialogue movement was at times motivated within the contexts of colonialism and imperialism. ${ }^{115}$ As Knitter argues, dialogue is often coercive and retaliatory. ${ }^{116}$ The social reality of the interreligious dialogue movement is that not every-

113 Swidler et al., Trialogue: Jews, Christians, and Muslims, 19.

114 Swing, The Coming of the United Religions, 76.

115 Moyaert, "Interreligious Dialogue," 193.

116 Knitter, Jesus and the Other Names. 
one is invited to dialogue and when present, not everyone is equally heard. ${ }^{117}$ The significance of URI to the field of interreligious dialogue is what Moyaert describes as the "process of reflection." 118 She argues that in a true dialogue, there must always be "intra-religious dialogue."119 This is the core value of URI that is pertinent to the interfaith field. Through interreligious dialogue, before one can meet the 'other', the process of reflection should emerge in an intra-religious context. Moyaert argues that this enables "shifts in meaning, new interpretations, [and] unexpected insights." 120 Such engagement is necessary in order for the interreligious encounter to be reflected "upon in an intra-religious way." 121 This is how URI reveals its strength as a global interfaith organization.

A second contribution of the United Religions to the interreligious dialogue movement is related to the first and that is a keen awareness of the excluded. Because of AI and Chaordic Organization, URI was able to carve a space for inclusive language to encourage a democratic engagement of diverse faiths and cultures. This success is partially related to the incorporation of these strategies into the developmental model of URI. These dialogical models and the commitment of URI to create inclusive language reveal the strength and power of the organization. In his monograph, Swing argues that the "presupposition in all of this that religion, in all its totality, has a vocation." ${ }^{222}$ Similar to Knitter, this vocation for Swing is rooted in the belief that religion is healing and can be a source of good in the world. ${ }^{123}$ This conviction led Swing to forge a path of dialogue that fostered critique among conservative Christian circles in the American context but also engendered a spirit of intra and inter-religious engagement with the 'other.'

Swidler notes that there are times in the interreligious dialogue movement when one encounters differences that are so vast that they require opposition. Indeed, Swidler argues that at times, particular religious ideologies are antithetical to human dignity and justice. "Important and contradictory differences between religions-ideologies do exist and at times warrant not dialogue but oppo-

117 United Religions Initiative Archives, 1995-2013. Box 1, Folder 3, Articles about Swing and the United Religions Initiative, 1996-2000, “The Rt. Rev. William E. Swing, 'Uniqueness of the United Religions.”"

118 Moyaert, "Interreligious Dialogue," 210.

119 Moyaert, "Interreligious Dialogue,” 210.

120 Moyaert, "Interreligious Dialogue," 210.

121 Moyaert, "Interreligious Dialogue," 210.

122 Moyaert, “Interreligious Dialogue," 210.

123 Moyaert, "Interreligious Dialogue," 210. 
sition." 124 Swing, not a novice in the interreligious dialogue field, is aware of these aspects of interfaith engagement. His personal experience indicates that interfaith engagement is not always pleasant and often includes criticism and censure. However, despite, these negative experiences during the foundational period of URI, Swing maintains, that dialogue is a necessary part of religious engagement. ${ }^{125}$ This necessity for him is related to his worldview that is ultimately theological and arises from his spiritual commitments. Swing believes that religion, as a whole, "has a discrete function to perform for health of the planet and all its life."126

For Swing, this theological notion is the driving force behind the creation of a 'United Religions.' Instead of remaining in the confessional realm, Swing argues that religion has a global responsibility. Religion and religious people have the potential to usher change and offer hope to the marginalized and oppressed. This orthopraxic commitment to interreligious dialogue has led URI down a path of spiritual discovery about the role of religion generally, and about their organization in particular, in healing global problems. Swing believes that multiple world issues can benefit from interreligious engagement. For example, women's empowerment, peace-building, youth initiatives, poverty alleviation, hunger, and abuse can all gain from the work and service of religiously committed individuals. However, Swing argues that while the United Religions is a step in the right direction, it is still a "young voice that belongs to coming generations." 127

Although Swing initially conceived of his organization as the "United Religions", after the Charter was created, it was officially named the United Religions Initiative. This name is an indication that for Swing, interreligious dialogue is still an evolving process. In his monograph, Swing writes that religious violence, hatred and strife continue to inform geopolitical infrastructure of the world. Despite the movement towards pluralism, in many regions, religious exclusivity still prevails. Despite these instances of violence and exclusivity, Swing finds hope in the youth. The youth, he argues, "heard something in the United Religions vision that resonated with their secret and higher hopes." 128 For Swing, the youth are defined by their acknowledgement of theological unity. This hope is what affirms for Swing that the youth will become co-creators of

124 Swidler et al., Trialogue: Jews, Christians, and Muslims, 23.

125 Swing, The Coming of the United Religions, 76.

126 Swing, The Coming of the United Religions, 76.

127 Swing, The Coming of the United Religions, 76.

128 Swing, The Coming of the United Religions, 76. 
an ongoing dialogical process. And one day, this small initiative, this "restless, young voice" will finally emerge as the United Religions of the world.

\section{Bibliography}

\subsection{Primary Sources}

United Religions Initiative Archives, 1995-2013. URI General History, Box 1, Folder 1, General History and Descriptions of the URI, 1995-1997.

Box 1, Folder 2, "Interfaith Service for the 50th Anniversary of the United Nations Charter, 1995."

United Religions Initiative Archives, 1995-2013. Box 1, Folder 3, Articles about Swing and the United Religions Initiative, 1996-2000.

Swing. William E. "An Invitation to Share the Vision/ An Invitation to Change the World," 1996.

Swing, William E. North American Interfaith Network Conference, Dallas, August 10, 1996.

Swing, William E. "Uniqueness of the United Religions", 1996.

URI General History, Box 1, Folder 4, "Swing’s Pilgrimage Around the World, 1996.

URI General History, Box 1, Folder 5, “Articles on Pilgrimage” from San Jose Mercury News, 1996.

URI General History, Box 1, Folder 12, “Negative Responses to URI, 1996-2000.” Penn Lee, "Midwives of a Common Good: The Myriad Friends of the United Religions Initiative", TOUchstone: A Journal of Mere Christianity, June, 2000.

URI General History, Box 1, Folder 18, "Preamble, Purpose, and Principles, 1999."

URI General History, Box 1, Folder 19, "Draft Charters, 1999."

Charles Gibbs, "Overview of Work on Charter/Detailed Description of Purpose Statement Development from June 1999 Summit to Present 10/11/99."

United Religions Initiative Proposed Revised Draft Charter, May 20, 1999."

URI General History, Box 1, Folder 20, "UN50 Interfaith Youth Conference: Correspondence, 1993-1995."

URI General History, Box 1, Folder 21, "UN50 Interfaith Youth Conference: Correspondence, 1995."

URI General History, Box 1, Folder 22, "UN50 Interfaith Youth Conference invitations 1994 1995."

URI History, Box 1, Folder 32-A, "Writings about URI by Swing and others, 1995-2005."

Speech by The Rt. Rev. Swing, William E. "United Religions Summit, June 24-28, 1996, Opening Speech."

N.N. Bridge to the One-World Religion: The Foundation" Times Digest and Newsbytes, February, 2000.

URI History, Box 1, Folder 34, Oxford Talk: “Interfaith Achievements? Initiatives Around the World, 1996.

URI History, Box 1, Folder 38, "Swing's travels to visit World Religious Leaders, 1996."

URI General History, Box 1, Folder 39, "Articles on Pilgrimage” from San Jose Mercury News Dispatches, 1996.

URI General History, Box 1, Folder 42, “United Religions Summit, 1996. 
URI General History, Box 1, Folder 43, "Summit Register and Agenda, 1996.

URI General History, Box 1, Folder 44, "Summit press packet, 1996.

URI General History, Box 1, Folder 45, "Conference Summary, 1996.

URI General History, Box 2, “Appreciative Inquiry, 1997-2001."

URI General History, Box 2, "Organisational Design Team, 1997-1999."

URI General History, Box 2, “Chaordic Design Work, 1997-1999.”

URI General History, Board of Directors/Global Council, Box 3, "URI Board Meetings."

URI General History, Board of Directors/Global Council, Box 3, "URI Corporate Minutes."

URI General History, Board of Directors/Global Council, Box 3, "URI Transitional Advisory

Group, 1999-2000."

\subsection{Secondary Sources}

Eck, Diana. The New Religious America: How a "Christian Country" Has become the World's Most Religiously Diverse Nation. San Francisco: Harper, 1992.

Fletcher, J. Hill. "Religious Pluralism in an Era of Globalization: The Making of Modern Religious Identity.” Theological Studies 69 (2008): 394-411.

Forward, Martin. Interreligious Dialogue; A Short Introduction. New York: Oneworld, 2001.

Gibbs, Charles and Sally Mahe. Birth of a Global Community: Appreciative Inquiry in Action. San Francisco: Lakeshore Communications, Inc, 2004.

Harold, Netland. Encountering Pluralism: The Challenge to Christian Faith \& Mission.

Westmont: InterVarsity Press, 2001.

Hick, John. An Interpretation of Religion: Human Responses to the Transcendent. New Haven: Yale University Press, 2005.

Hick, John and Paul F. Knitter. eds. The Myth of Christian Uniqueness: Toward a Pluralistic Theology of Religions. New York: Wipf and Stock Publishers, 2005.

Knitter, Paul F. Jesus and the Other Names: Christian Mission and Global Responsibility. New York: Orbis Books, 1996.

Knitter, Paul F. No Other Name? A Critical Survey of Christian Attitudes towards the World Religions. New York: SCM Press, 1985.

Knitter, Paul F. One Earth, Many Religions: Multifaith Dialogue and Global Responsibility. New York: Maryknoll, 1995.

Küng, Hans. Global Responsibility: In Search of a New World Ethic. New York: Crossroads Publishing, 1991.

Lawrence, Trudi. “Theosophy, Ecology \& Pan-Religion.” Tradition in Action. January 11, 2011. https://www.traditioninaction.org/History/G_011_PanReligion.html (accessed: 24.5.2020).

Mahé, Sally. "United Religion Initiative: Global Community Emerging." Integral Review 8 (2012): 96-100.

Patton, Michael Quinn. Qualitative Research \& Evaluation Methods. New York: Sage Publications, 2002.

Swidler, Leonard, Khalid Duran, and Reuven Firestone. Trialogue: Jews, Christians, and Muslims in Dialogue. New London: Twenty-Third Publications, 2007.

Swing, William E. The Coming of the United Religions. Grand Rapids: CoNexus Press, 1998. 
Cheetam, David, Thomas, David, and Douglas Pratt, eds. Understanding Interreligious

Relations. Oxford: Oxford University Press, 2013.

Thomas, M. A. Towards a Wider Ecumenism. Bangalore: Asian Trading Company, 1993. Ziebertz, Hans-Georg and Friedrich Schweitzer, eds. Dreaming the Land: Theologies of Resistance and Hope. London: Transaction Publishers, 2007.

\section{Annex: United Religions Initiative Charter Preamble}

We, people of diverse religions, spiritual expressions and indigenous traditions throughout the world, hereby establish the United Religions Initiative to promote enduring, daily interfaith cooperation, to end religiously motivated violence and to create cultures of peace, justice and healing for the Earth and all living beings.

We respect the uniqueness of each tradition, and differences of practice or belief.

We value voices that respect others and believe that sharing our values and wisdom can lead us to act for the good of all.

We believe that our religious, spiritual lives, rather than dividing us, guide us to build community and respect for one another.

Therefore, as interdependent people rooted in our traditions, we now unite for the benefit of our Earth community.

We unite to build cultures of peace and justice.

We unite to heal and protect the Earth.

We unite to build safe places for conflict resolution, healing and reconciliation.

We unite to support freedom of religion and spiritual expression, and the rights of all individuals and peoples as set forth in international law.

We unite in responsible cooperative action to bring the wisdom and values of our religions, spiritual expressions and indigenous traditions to bear on the economic, environmental, political and social challenges facing our Earth community.

We unite to provide a global opportunity for participation by all people, especially by those whose voices are not often heard.

We unite to celebrate the joy of blessings and the light of wisdom in both movement and stillness.

We unite to use our combined resources only for nonviolent, compassionate action, to awaken to our deepest truths, and to manifest love and justice among all life in our Earth community.

The purpose of the United Religions Initiative is to promote enduring, daily interfaith cooperation, to end religiously motivated violence and to create cultures of peace, justice and healing for the Earth and all living. 